steam pressures (170-175 lb. per sq. in.) were maintained except in Trial 11.

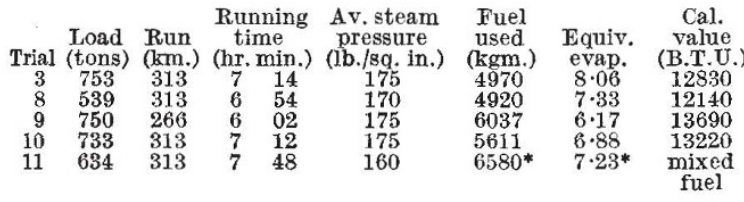

Representative figures for 'equiv. evap.' of coals under conditions of these trials are: Welsh or American coal, 9.4; South African, 8.7 ; Indian, 8.2.

In all these trials the charcoal was ground in edge-runner mills. For material used in Trials 3 and 8, the following is a specimen sieve analysis.

$\begin{array}{lrrrrrrrl}\text { Less than } & & 8 & 16 & 30 & 60 & 100 & 200 & \text { I.M.M. } \\ \text { Greater than } & 8 & 16 & 30 & 60 & 100 & 200 & & \text { I.M.M. } \\ & 15 & 15 & 12 & 16 & 9 & 13 & 19 & \text { per cent }\end{array}$

Coarser material (less than $\frac{5}{8}$ in.) was used in Trials 9 and 11, while that used in Trial 10 was intermediate (less than 1 in.). The trial results fell off accordingly, Trial 9 being inferior to Trial 10, which is inferior to Trials 3 and 8 . With these coarser materials it was observed that a larger proportion of fuel was carried away unburned and accumulated in the smoke-box. In Trial 11 we remedied this by burning the briquettes in 50/50 mixture with an American coal, but this and other similar trials were unsatisfactory for, although no data are available as to the performance of the American coal used in Trial 11, if the average figure of $\mathbf{9 \cdot 4}$ for equiv. evap. is taken, it indicates that the briquettes were burned inefficiently. The failure of such trials is due to troublesome clinker formation caused, it is thought ${ }^{2}$, by admixture of the siliceous ash of the coal with the basic ash of the charcoal. A similar formation of clinker occurs with charcoal-pitch briquettes to which 5 per cent of siliceous fine soil has been added.

Owing to the large demand for pitch for various war purposes, we tried to do without this constituent. The briquettes, however, disintegrated in use and gave poor results (equiv. evap. 5.08 and 4.62 in Trials 5 and 7). These failures occurred although the briquettes, which had been given a higher proportion of oil, resembled the successful ones in calorific value (12310 B.T.U.) and ash content (about 10 per cent). Considerable quantities of briquettes rejected owing to mechanical weakness, damage by rain, etc., were remade and satisfactorily disposed of in shunting engines or used to fire a stationary boiler, for which purpose they roughly equalled coal.

It became clear at an early stage of our work that the grinding of charcoal to a suitable powder was the most difficult part of the whole process. The product obtained from edge-runner mills is satisfactory, but much difficulty was experienced with charcoal pulverized in beater type mills which continually produced weak or badly cracked briquettes. Internal strains are gradually released when charcoal is moistened, and we have some reason to think that this difference in behaviour depends in part on the fact that charcoal was moistened before being fed to edge-runner mills but was fed dry to beater type mills. Neither sieve analysis nor microscopical examination of the fine particles revealed any notable feature other than the rather less rounded shape of particles obtained from a beater type mill.

One satisfactory full-scale trial was carried out using briquettes made from charcoal which was wetted and then crushed by an ordinary garden roller and stirred by rakes to prevent packing of the fragments into a resistant bed. In this trial the briquettes were burned in 50/50 mixture with American coal, some steam pressure being lost owing to formation of clinker. (Trial 12. Load 777 tons; run $313 \mathrm{~km}$. ; running time $9 \mathrm{hr} .34 \mathrm{~min}$. ; av. steam pressure $150 \mathrm{lb} / \mathrm{sq}$. in.; fuel used 4,938 kgm.; equiv. evap. $8 \cdot 26$.) Since edge-runner mills were not available for production of briquettes on a larger scale, we have devised a type of bull-drawn roller in which twin rollers are set at an angle so as to combine the shearing and crushing action such as occurs in an edge-runner mill. Strong, mechanically sound briquettes have been consistently produced by this simple means.

The experiments described above were carried out in 1942 and concluded the first part of our inquiry. We have since been filling in the gaps with a long series of fairly obvious multi-factor experiments of which the results will be published later. In 1943 some 1,000 tons of charcoal-pitch briquettes were produced, under the direction of Mr. J. Smith, chief conservator of forests, in a first attempt to use the process on a larger scale, but the briquettes disintegrated when used in main-line locomotives and had to be burned in less severe conditions. With extemporized equipment, unskilled labour and limited supervision it is difficult to turn out large amounts of a good and uniform product. Charcoal burning is now being increased, and a small briquetting factory, embodying normal industrial equipment, is in operation. In this a mixture of charcoal (85 parts) and Mexphalte $D H \quad 75 / 85$ (15 parts) is steam-heated and pressed between rollers, gum and oil being omitted. The product is strong and waterproof and does not disintegrate in the fire-box. Owing to formation of clinker, however, locomotive fuel trial results have been poor (equiv. evap. $5 \cdot 08,4 \cdot 95$ ). This difficulty probably arose from use of dirty charcoal and therefore should soon be eliminated or reduced.

Our thanks are due to the General Manager, Sudan Railways, for help in the well-equipped Atbara workshops and for the skilled and willing co-operation of his staff. We are also indebted to Dr. A. J. Henry, Government analyst, for determinations of calorific value.

${ }^{1}$ Joseph, A. W., and Whitfield, B. W., J. Soc. Chem. Ind., 15, 190 (1921). 2 Searle, A. B., "Refractory Materials" (C. Griffin and Co., Ltd., 1917), 48 .

\section{RESEARCH PROGRAMME FOR SOUTH WALES}

IN an inaugural address to the South Wales Institute of Engineers at Cardiff on January 20, on "Industrial Planning and Research: Catchwords or Realities ?", Dr. F. J. North emphasized that our plans for the expansion of industry and for the betterment of social conditions will be useless unless the availability of the means for giving effect to them has been assured. What is technically possible is not necessarily economically profitable; the success of a venture depends on a market as well as upon raw materials, and the value of one industry is related to its effect upon others. The single-track approach to many of our problems, Dr. North said, is largely due to the gap which exists between scientific knowledge and popular comprehension of it, a gap which will only be permanently bridged when a new attitude towards science is adopted by those responsible for 
the educational system of Great Britain. Discussing particular proposals such as coal and its hydrogenation, the Severn Barrage scheme and the like as contributions to Welsh reconstruction, he pointed out that such questions cannot be considered solely in terms of regional standards or local expediency. The first step in giving effect to plans for social betterment in all its aspects is to make the nation realize the extent to which its welfare depends upon coal, upon those who make it available for use, and upon those who attempt to discover how best to use it.

After reviewing the position of coal in the economic picture, Dr. North discussed the aims and objects of research. $\mathrm{He}$ deprecated the distinction between fundamental and industrial research as helpful neither to science nor to industry, and emphasized that research is a continuous process in which one step prepares the way for another. In the past, largely because of the abundance of the world's natural wealth to which Great Britain has access, industry in general prospered without much recourse to the results of research, but now as a nation we have to recognize the desirability of doing willingly in peacetime some of the things we are doing under compulsion in war-time. The only way to ensure a future adequacy of research is to create conditions affecting remuneration, prestige and equipment, in which research will be an attractive career, while those concerned with the commercial side of industry must be encouraged to develop a scientific outlook which will enable them better to appreciate and to respond to changes in the availability of raw materials, in public taste, and in technical possibilities. Dr. North urged that the right line of advance is to extend the existing facilities by more generous appropriations to the Department of Scientific and Industrial Research, more generous grants to the universities and more generous support from firms and industries that have not yet accepted their full share of the burden. Closer collaboration between research organizations is also required, and while there are in South Wales all the necessary elements for concerted research in the interest of local industry, there are few signs of general co-ordination. $\mathrm{He}$ believes that regional commissioners for the co-ordination of research might help those concerned in the industries of such a welldefined area to know what has been done or is contemplated, and at the same time keep the appropriate government department aware of the collective needs of the area.

In regard to a research programme for South Wales, Dr. North considers that a prime necessity is the vigorous prosecution of the survey of the ehemical and physical properties of all the coal seams, and the completion of the geological re-survey of the coalfield. The chemical information would indicate the nature and distribution of the various kinds of coal present, and the geological survey would indicate where and under what conditions they can be mined. Given a fair idea of the trend of industrial development, it would be possible to pay special attention to mining methods appropriate to the kinds of coal likely to be in greatest demand, and to the size and degree of purity of the coal. Co-ordinated work of this kind would help the mines to meet the increasingly exacting demands of industry; but mining research should also be encouraged to indicate the coals which can be most safely and cheaply won, leaving to industry the onus of finding efficient ways of using them. Knowledge of the varieties of coal and their potentialities must be the basis of any attempt to explore the possibilities of the underground gasification of coal, as well as of decisions concerning the kinds of new industry that can be developed and the localities in which they should be founded. Such decisions, in turn, afford guidance to those concerned in determining the position and character of new housing schemes, the facilities for access to them and the amenities required. Again, South Wales cannot afford to be unconcerned at the general lack of official interest in geological exploration, since its industries require minerals and ores not locally available.

Dr. North suggested that the basic principles should be to develop industries in which there is the greatest possible difference between the value of the raw materials used and that of the commodity or article produced, and in which the largest possible part of that difference is represented by payments to those whose services have effected the difference. Scientific and technical workers must be the guides and not the tools of the politician and financier, and the industries selected for foundation or expansion should be those which can be self-supporting at least within a reasonably short time. We should think along the lines of organic evolution, in which there is a continual reaction to changing environment by organisms which possess, in some degree, the capacity to modify or control it. An important function of the South Wales Institute of Engineers is to help create public awareness in matters appertaining to the industrial future of the region.

\section{INDUSTRIAL FATIGUE AND ABSENTEEISM}

7 HE Industrial Health Research Board has issued a pamphlet (London: H.M. Stationery Office. $3 d$.) giving a survey in non-technical language of the problems of absence from work and prevention of fatigue. Merely vague statements about the excessive amount of absenteeism are valueless. It is necessary to know how much there is, to what extent it is greater than in peace-time and the conditions leading to it.

The Industrial Health Research Board has been studying the problem throughout the war years in numbers of factories of varying size and kind, and the records have been analysed. In normal times, it was usually estimated that absence should not exceed five per cent of the possible hours of work a year. During the war years, this amount has increased and is now between six and eight per cent for men and between ten and fifteen per cent for women. There are considerable variations from factory to factory. Factories of recent growth, situated far from the homes of those who work in them, employing women unused to factory work, show an absence-rate almost twice as high as some of the old-established works within easy travelling distance of the workers' homes.

In most factories it was found that the women lost about twice as much time as the men, and married women lost up to three times as much as single women. The conditions conducive to absence include excessive hours of work, bad working conditions, unexplained idle time, wages problems, lack of cooperation between managers and workers. The factory, however, is not the whole environment of the worker; conditions outside the factory also play a part. Some of these refer to transport difficulties, 